\title{
REFLEKSI PENDIDIKAN IPA SEKOLAH DASAR DI INDONESIA (Relevansi Model Pendidikan Paulo Freire dengan Pendidikan IPA di Sekolah dasar)
}

\author{
Anatri Desstya ${ }^{1)}$, Istiani Indah Novitasari' ${ }^{2)}$, Aldi Farhan Razak ${ }^{3)}$, Kukuh Sandy Sudrajat ${ }^{4}$ ) \\ Pendidikan Guru Sekolah Dasar FKIP, Universitas Muhammadiyah Surakarta \\ 1ad121@ums.ac.id; ${ }^{2}$ istiani.indah96@gmail.com; ${ }^{3}$ aldifarhanrazak@gmail.com; ${ }^{4}$ sudrajatsandy@ gmail.com
}

\begin{abstract}
This study aimed to describe: the process of science education in elementary schools in line with expectations at this time, the educational model Paulo Freire, the purpose of education Paulo Freire, and its relevance to science education in primary schools. This study is a library research. The main data sources obtained from books, journals and other writings related to science education in primary schools and the educational model of Paulo Freire. Data collection techniques with identifying information of the books, previous research reports, journals, articles, web, or other information. This research uses descriptive analysis method. The data analysis includes the decomposition of matter suitable object of study then described and analyzed for the conclusion, namely 1) science education in elementary routed through direct experience, conducted inquiry scientifically develop process skills and scientific attitude, 2) educational model's Paulo Freire states on education dialectical, liberating education and shackled, and educational humanism, 3) he conformity of Paulo Freire's education with science education in elementary school, namely in the change in the quality of critical thinking, 4) Relevance between the two in concepts, goals, positions of educators and learners.
\end{abstract}

Keywords: Elementary School, Elementary Science Education, Educational of Paulo Freire

\section{PENDAHULUAN}

Pendidikan sebagai kunci utama bagi bangsa dalam membangun masa depannya. Dengan pendidikan, suatu bangsa dapat membuka cakrawala dunia dan mampu bersaing dalam berbagai bidang. Penguasaan dalam bidang teknologi merupakan wujud persaingan yang mengindikasikan majunya suatu bangsa. Kemajuan teknologi didasari oleh pengetahuan dasar, yaitu Ilmu pengetahuan alam (IPA). Dewey (2001: 34) dalam Freire (2007: 76), pendidikan adalah proses untuk membentuk kemampuan dasar yang bersifat fundamental, baik yang berkaitan dengan daya intelektual, ataupun daya emosional yang dipusatkan pada tabiat manusia dan terhadap sesamanya. Driyarkara dalam Yamin (2010: 65), pendidikan adalah proses memanusiakan manusia muda yang hendaknya dipahami sebagai proses humanisasi, artinya sikap, perbuatan dan kegiatan seseorang bersifat manusiawi.

Upaya untuk mencerdaskan kehidupan bangsa, mengembangkan manusia Indonesia seutuhnya, yang beriman dan bertakwa terhadap Tuhan Yang Maha Esa dan berbudi pekerti luhur, berpengetahuan dan keterampilan, sehat jasmani dan rohani, kepribadian yang mantap dan mandiri serta rasa tanggung jawab kemasyarakatan dan kebangsaan yang merupakan tujuan pendidikan nasional kita, telah diupayakan pemerintah dengan menyelenggarakan pendidikan formal yang ditempuh mulai dari jenjang sekolah dasar.

Sekolah dasar merupakan bagian dari satuan pendidikan dasar yang menjadi program wajib belajar pemerintah, yang diselenggarakan selama 6 tahun. Di sekolah 
dasar, proses pendidikannya dirancang agar mampu melanjutkan ke pendidikan menengah dan pendidikan tinggi. Untuk menjadi bangsa yang maju dalam hal penguasaan teknologi, maka pendidikan tentang IPA telah diajarkan di sekolah dasar (Djumhana, 2007: 45). Selama ini, indikator keberhasilan dalam pendidikan menekankan pada kemampuan intelektual, kemampuan dalam menciptakan dan menerapkan suatu produk teknologi, tanpa memperhatikan sisi lain, seperti karakter sosial maupun spiritual. Hal tersebut semakin menunjukkan bahwa proses pelaksanaan pendidikan di Indonesia tidak sejalan dengan yang telah dicita-citakan.

Penguasaan teknologi berpengaruh terhadap kehidupan manusia. Teknologi yang dikembangkan oleh manusia digunakan kembali untuk memudahkan kehidupan manusia. Dengan demikian, sangat diperlukan upaya untuk menyelenggarakan pendidikan yang memanusiakan, seperti yang dimaksudkan oleh Paulo Freire, seorang doktor bidang pendidikan di Brazil. Freire mengungkapkan, pendidikan harus memiliki orientasi pada pengenalan realitas diri manusia dan dirinya sendiri. Pendidikan harus melibatkan tiga unsur dalam prosesnya: pengajar, pelajar, dan kenyataan dunia. Menurutnya, pendidikan diibaratkan sebagai sebuah bank, pelajar sebagai objek investasi dan sumber deposito potensial, sementara depositonya adalah ilmu pengetahuan, dan guru sebagai investornya. Freire (2009: vii), fitrah manusia sejati adalah menjadi subjek, bukan objek. Mereka merupakan subjek yang sadar, berusaha menyelesaikan permasalahan duniawi serta kenyataan yang menindas. Dunia ini bukanlah sesuatu yang tercipta dengan sendiri, sehingga manusia harus bersikap kritis dengan menggunakan bahasa pikiran.

Mengamati urgensinya mengajarkan IPA di sekolah dasar agar suatu bangsa mempunyai bekal untuk mampu menguasai teknologi, tentang pelaksanaan proses pendidikan di Indonesia yang tidak sejalan dengan cita-cita, dan keterkaitannya dengan pemikiran Paulo Freire tentang pendidikan, maka perlu adanya kajian lebih lanjut tentang model pendidikan Paulo Freire dan relevansinya dengan pendidikan IPA di sekolah dasar dari berbagai aspek. Bagaimanakah proses pendidikan IPA di sekolah dasar yang sesuai dengan harapan pada saat ini? Bagaimana model pendidikan Paulo Freire? Apakah tujuan dari pendidikan Paulo Freire? Bagaimana relevansi model pendidikan Paulo Freire dengan pendidikan IPA di sekolah dasar?

IPA merupakan tubuhnya pengetahuan, terdiri dari sekumpulan fakta, konsep, teori, dan hukum, ditemukan melalui proses ilmiah. IPA sebagai attitude dan melibatkan cara berfikir. Salah satu alasan IPA dimasukkan ke dalam kurikulum sekolah dasar, adalah bahwa IPA merupakan pengetahuan dasar suatu teknologi. Harapan ke depan, dengan membekali materi IPA di sekolah dasar, bangsa ini akan menguasai teknologi.

Pembelajaran IPA sebaiknya dilakukan dengan discovery learning, yang didasarkan pada aktivitas pengamatan, menginferensi, dan mengkomunikasikan. Aktivitas ini merupakan inti dari keterampilan proses (scientific process). Oleh karena itu, proses pembelajaran IPA harus disesuaikan dengan hakikatnya dan karakter siswa sekolah dasar. Siswa sekolah dasar berada pada tahap perkembangan operasional konkrit, 
masih sangat membutuhkan benda-benda konkrit untuk membantu pengembangan kemampuan intelektualnya. Untuk menemukan suatu produk sains, dan kemudian memahaminya, siswa sekolah dasar lebih diarahkan untuk proses menemukannya sendiri. Siswa diberikan kesempatan untuk memupuk rasa ingin tahu, sehingga mampu mengembangkan kemampuan bertanya, mencari jawaban berdasar bukti serta mengembangkan berpikir ilmiah. Siswa cenderung aktif selama pembelajaran untuk membangun (mengkonstruksi) pengetahuannya melalui serangkaian kegiatan agar pembelajaran bermakna bagi siswa. Siswa sebagai pusat pembelajaran, guru sebagai fasilitator.

Paulo Freire, seorang doktor pendidikan di Brazil, yang mengkritik dampak yang ditimbulkan oleh pendidikan sekolah terhadap masyarakat luas. Freire mengemukakan tentang pendidikan pembebasan, bukan pendidikan untuk penguasaan (dominasi). Menurutnya, belajar adalah pekerjaan yang cukup berat, menuntut kemampuan intelektual yang diimbangi dengan sikap kritik-sistematik dapat diperoleh dengan praktik langsung. Pendidikan yang selama ini berlangsung dirasa telah membunuh semangat, keingintahuan, dan kekreativitasan kita. Mata pelajaran sekolah mencerdakan siswa, tetapi kecerdasan yang hanya berkaitan dengan teks, tidak akan menjadi kritik yang mendasar terhadap teks itu sendiri.

Freire memperkenalkan konsep pendidikan dialogis. Melalui pendidikan dialogis, Freire membawa masyarakat Brazil kembali kepada fitrahnya, yaitu manusia merdeka yang kritis dan kreatif. Pendidikan yang selama ini berlangsung diibaratkan oleh Freire sebagai pendidikan gaya bank, yang hanya menjadikan peserta didik sebagai objek yang terus menerima. Peserta didik ibarat deposito yang dapat diisi kapan saja, dengan muatan apa saja. Pendidikan semacam ini akan mematikan sikap kekritisan siswa. Fitrah manusia adalah sebagai pelaku, bukan objek. Manusia harus bersikap kritis dengan menggunakan bahasa pikiran. Di dalam konteks pendidikan, Freire menyebutkan bahwa kedudukan guru dan siswa adalah sama-sama sebagai subjek. Kedua pihak dapat saling mengisi, bukan hanya diisi.

\section{METODE PENELITIAN}

Jenis penelitian ini adalah penelitian deskriptif, dengan mengkaji dan mendeskripsikan isi dari literatur yang berupa buku, dokumen resmi pemerintah, maupun laporan hasil penelitian dari penelitian terdahulu. Sumber data utama dari penelitian ini akan diperoleh melalui penelusuran pustaka, yaitu data yang diperoleh dari buku Ira Shore dan Paulo Freire (2001), jurnal dan tulisan lain yang berkaitan dengan pendidikan IPA di sekolah dasar dan model pendidikan pembebasan dari Paulo Freire. Teknik pengumpulan data dilakukan dengan mengidentifikasi informasi terkait dari buku-buku, laporan penelitian terdahulu, jurnal, artikel, web, ataupun informasi lainnya yang berhubungan dengan judul penelitian terkait untuk mencari aspek-aspek yang telah ditentukan. Data pada penelitian ini dilakukan dengan cara analisis deskriptif. Analisis data mencakup penguraian masalah objek kajian kemudian dideskripsikan dan dianalisis untuk memperoleh kesimpulan. 
HASIL DAN PEMBAHASAN

Proses pendidikan IPA di Sekolah Dasar

Ilmu Pengetahuan Alam pada hakikatnya merupakan body of knowledge (tubuhnya pengetahuan), a way of investigation (cara untuk melakukan penyelidikan), dan scientific attitude (sikap ilmiah). IPA sebagai body of knowledge merupakan hasil temuan yang dilakukan para ilmuan, yang berupa fakta, konsep, prinsip, hukum, teori maupun model. Temuan-temuan tersebut diperoleh melalui proses penyelidikan dengan metode discovery maupun inquiry. Selama melakukan penyelidikan ini, sikap ilmiah (scientific attitude) sangat diperlukan dan akan mulai terbentuk. Sikap ilmiah yang diharapkan meliputi objektif, tidak tegesaagesa, berhati terbuka, dapat membedakan antara fakta dn pendapat, tidak bersifat memihak pada satu pendapat tertentu, tidak mendasarkan kesimpulan berdasarkan prasangka, tidak percaya akan takhayul, tekun dan sabar dalam memecahkan masalah, mengkomunikasikan hasil temuannya untuk dikritisi dan disempurnakan, dapat bekerja sama dengan orang lain, dan selalu memiliki rasaa ingin tahu.

Pendidikan Ilmu Pengetahuan Alam pada hakikatnya merupakan suatu pemahaman tentang pentingnya mempelajari alam sehingga akan membawa manusia pada kehidupan yang bermakna dan bermartabat. Dalam pendidikan IPA menjelaskan pembentukan berfikir manusia dalam kaitannya dengan mempelajari alam sehingga manusia menjadi mengerti, beretika, dan lebih dekat dengan Tuhannya. Hakikat pendidikan IPA adalah membelajarkan peserta didik untuk memahami hakikat IPA, dengan memasukkan unsur sikap, content, dan proses.

Jika guru di sekolah dasar memahami secara mumpuni tentang hakikat pendidikan IPA, hal ini akan memungkinkan bagi guruguru sekolah dasar untuk menjalankan tugas profesional, yaitu pembelajaran IPA. Menurut Permendiknas No. 22 Tahun 2006, kompetensi dalam pembelajaran IPA di SD/MI terdiri atas: 1) menguasai pengetahuan tentang berbagai jenis dan perangai lingkungan alam dan lingkungan buatan dalam kaitan dengan pemanfaatan bagi kehidupan sehari-hari; 2) mengembangkan keterampilan proses sains; 3) mengembangkan wawasan, sikap dan nilai-nilai yang berguna bagi siswa untuk meningkatkan kualitas kehidupan seharihari; 4) mengembangkan kesadaran tentang keterkaitan yang saling mempengaruhi antara kemampuan sains dan teknologi dengan keadaan lingkungan serta pemanfaatannya bagi kehidupan nyata sehari-hari; dan 5) mengembangkan kemampuan siswa untuk menerapkan IPTEK serta keterampilan yang berguna dalam kehidupan sehari-hari, maupun untuk melanjutkan pendidikannya yang lebih tinggi.

Beberapa alasan mata pelajaran IPA dimasukkan ke dalam kurikulum sekolah adalah: (1) IPA berguna bagi suatu bangsa, karena IPA merupakan pengetahuan dasar dari teknologi, yang merupakan tulang punggung dasri suatu bangsa. (2) IPA mampu mengembangkan kemampuan berpikir kritis dan sikap ilmiah yang membentuk insan Indonesia yang berkepribadian luhur, dan (3) IPA mempunyai nilai-nilai pendidikan yang dapat membentuk kepribadian anak secara keseluruhan (Samatowa, 2011: 6). Dengan 
demikian, dapat digarisbawahi bahwa tujuan pendidikan IPA di sekolah dasar adalah membelajarkan siswa sekolah dasar agar memahami hakikat IPA, agar mampu berfikir kritis, dan mempunyai kepribadian luhur sebagai dasar dalam penguasaan teknologi.

Teori perkembangan kognitif Piaget menyatakan bahwa anak sekolah dasar berada pada tahap operasional konkrit (7-12 tahun). Mereka akan lebih mudah memahami sebuah konsep melalui pengalaman yang konkrit. Karakteristik tersebut dapat digunakan oleh guru sekolah dasar dalam melakukan pembelajaran IPA yang mengacu pada kompetensi yang terdapat dalam Permendiknas No 22 Tahun 2006 tersebut.

Dengan demikian, dapat disimpulkan bahwa pendidikan IPA di sekolah dasar adalah upaya membelajarkan peserta didik untuk memahami hakikat IPA, dengan memasukkan unsur sikap, content, dan proses, yang dilakukan dengan memberikan suatu pengalaman belajar yang konkrit, yaitu dengan metode inquiry maupun discovery.

\section{Model Pendidikan menurut Paulo Freire}

Penelitian ini memfokuskan pada pembahasan tentang cara, strategi, atau pendekatan dalam mentransfer ilmu pengetahuan dari Paulo Freire dari 3 aspek, yaitu pendidikan dialektis, pendidikan membebaskan, dan pendidikan humanistis.

Proses pembelajaran merupakan usaha untuk memperoleh pengetahuan. Proses mentransfer ilmu pengetahuan dipandang sebagai aksi budaya untuk membebaskan siswa dari belenggu ketidaktahuannya. Siswa memerankan diri sebagai subjek untuk berdialog dengan gurunya. Dialog yang sesungguhnya akan menyatukan subjek-subjek yang berusaha mendapatkan pengetahuan akan suatu objek yang dalam konteks ini berperan sebagai media komunikasi di antara mereka. Sejak awal siswa harus memposisikan diri sebagai subjek yang kreatif. Dengan pendidikan secara dialektika, Paulo Freire mampu membawa kembali masyarakatnya menuju fitrahnya, yaitu manusia merdeka yang kritis dan kreatif.

Dialog menjadi kunci dari konsep pendidikan Freire. Pendidikan secara dialektika mampu mentransformasi nilai kejujuran, keadilan, kemanusiaan, kesetiakawanan, profesionalisme, keluhuran, kedisiplinan, dan ketulusan. Pendidikan secara dialektika merupakan hal penting karena bukan sekedar transfer ilmu, tetapi pembentukan karakter. Selama ini, dalam proses pembelajaran membahas pada sesuatu yang abstrak, tidak sesuai dengan kehidupan sebenarnya.

Dalam prosesnya, belajar harus memberi kesempatan bagi siswa untuk mengetahui konsep yang dibicarakan. Sebuah tindakan selalu mengimplikasikan refleksi dan aksi berikutnya. Usaha untuk mendapatkan pengetahuan mencakup sebuah dialektika yang beranjak dari aksi menuju refleksi, dan dari refleksi menuju aksi yang baru. Siswa harus melewati proses abstraksi yang sebenarnya, dengan cara merefleksikan seluruh aksi-objek, dengan mengkaji ulang tujuan hidup mereka di dunia.

Pendidikan dialektis melibatkan unsur pengajar dan pelajar, yang merupakan subjek yang sadar, serta realitas dunia sebagai objek yang disadari (Freire, 2009: 45). Melalui dialog, pendidik dan peserta didik melakukan komunikasi dua arah yang 
terjalin secara terbuka. Dengan adanya keterbukaan melalui dialog, pendidikan dalam bentuk doktrinasi dapat dihindarkan. Dialog merupakan metode tepat untuk memperoleh pengetahuan, sehingga guru dan murid harus menggunakan pendekatan ilmiah dalam melakukan dialog sehingga akan memperoleh realitas secara benar. Bagi Freire, mengetahui suatu hal/ konsep tidak sama dengan mengingatnya.

Paulo Freire mengedepankan sistem pendidikan yang membebaskan, dan tidak membelenggu. Pada model pendidikan yang membelenggu, siswa merupakan objek pasif dan tidak dituntut untuk berpartisipasi aktif dalam proses belajar. Siswa hanya diisi kata-kata oleh guru. Guru mengajarkan kepada siswa seolah-olah dirinya terpisah dari kehidupan nyata, seolah-olah bahasa pemikiran itu bisa muncul tanpa kenyataan yang ada. Kurangnya guru dalam menghargai kebebasan siswa, merupakan cerminan pendidikan membelenggu, yang menanamkan kesadaran yang salah kepada siswa, yang pada akhirnya mereka hanya mengikuti alur kehidupan. Guru melakukan tindakan manipulatif dengan siswa sebagai objeknya. Pendidikan membebaskan yang digagasnya, merupakan proses ketika guru mengkondisikan siswa untuk mengenal dan mengungkap kehidupan yang real secara kritis. Tidak adanya dikotomi antara subjek dan objek. Pendidikan secara dialektis merupakan wujud dari pendidikan yang membebaskan merupakan upaya untuk memperoleh pengetahuan dan kreativitas dimana siswa bersama-sama dengan guru menjadi subjek pengetahuan.

Konsep pendidikan humanis yang digagasnya, mulai ada ketika ada apresiasi tentang hubungan dialektis antara kesadaran manusia dan dunia, atau antara manusia dan dunianya. Pendidikan humanis memberikan kebebasan yang luas untuk berfikir kritis, dan semakin banyak yang dikritis dan mengkritisi. Hal ini merupakan sebuah kondisi sejajar antar manusia yang satu dengan yang lain. Dominasi atas salah satu pihak merupakan sebuah bentuk penindasan, sehingga keadaan-keadaan tersebut harus dilawan.

Berdasarkan uraian di atas, dapat diambil pokok-pokok dalam model pendidikan Paulo Freire, yaitu konsep pendidikan yang berwawasan humanis. Antara pendidik dan peserta didik terjadi keharmonisan dalam melakukan dialog dalam menemukan suatu konsep pengetahuan.

\section{Tujuan dari Pendidikan Paulo Freire}

Paulo Freire, seorang tokoh pelopor critical pedagogy, yaitu pendekatan pembelajaran yang membantu siswa melalui dominasi pertanyaan dan tantangan serta keyakinan dan praktik. Tujuan dari critical pedagogy adalah untuk memberdayakan peserta didik, membantu mereka agar membantu dirinya sendiri, dan membebaskan dari penindasan (Siswanto, 2007: 15). Pendidikan yang membebaskan dari Paulo Freire ini adalah Pendidikan yang menumbuhkan kesadaran kritis, yang ditandai dengan kedalaman menafsirkan masalah-masalah, percaya diri dalam berdiskusi, mampu menerima dan menolak. Pada tingkat ini orang mampu merefleksi dan melihat hubungan sebab akibat. Pendidikan Paulo Freire merupakan pendidikan yang berwawasan humanis, yang bertujuan agar dapat menghasilkan perubahan pada diri siswa baik perubahan dalam kualitas berfikir, kualitas pribadi, 
kualitas sosial, kualitas kemandiriannya dan kualitas kemasyarakatannya.

\section{Relevansi Model Pendidikan Paulo Freire Dengan Pendidikan IPA di Sekolah dasar}

Pembatasan kajian model pendidikan Paulo Freire dan pendidikan IPA di sekolah dasar adalah pada konsep, tujuan, metode pendidikan, posisi pendidik, serta posisi peserta didik, yang masing-masing disajikan dalam table 1 berikut:

Tabel 1. Relevansi Pendidikan Paulo Freire dengan Pendidikan IPA di Sekolah Dasar

\begin{tabular}{|l|l|l|}
\hline \multicolumn{1}{|c|}{ Aspek } & \multicolumn{1}{|c|}{ Pendidikan Paulo Freire } & \multicolumn{1}{c|}{$\begin{array}{c}\text { Pendidikan IPA di SEKOLAH } \\
\text { DASAR }\end{array}$} \\
\hline Konsep & Pendidikan humanis & $\begin{array}{l}\text { Pendidikan untuk mengembangkan } \\
\text { kemampuan berpikir kritis dan sikap } \\
\text { ilmiah }\end{array}$ \\
\hline Tujuan & $\begin{array}{l}\text { Dapat menghasilkan perubahan pada diri } \\
\text { siswa baik perubahan dalam kualitas } \\
\text { berfikir, kualitas pribadi, kualitas sosial, } \\
\text { kualitas kemandiriannya dan kualitas } \\
\text { kemasyarakatannya }\end{array}$ & $\begin{array}{l}\text { Membelajarkan siswa sekolah dasar agar } \\
\text { memahami hakikat IPA, agar mampu } \\
\text { berfikir kritis, dan mempunyai } \\
\text { kepribadian luhur sebagai dasar dalam } \\
\text { penguasaan teknologi }\end{array}$ \\
\hline Metode & $\begin{array}{l}\text { Menekankan pada kebebasan intelektual } \\
\text { antara pendidik dengan peserta didik, } \\
\text { melalui dialog terbuka }\end{array}$ & $\begin{array}{l}\text { Metode inquiry dan discovery yang } \\
\text { menekankan pada keterampilan proses }\end{array}$ \\
\hline $\begin{array}{l}\text { Posisi } \\
\text { pendidik }\end{array}$ & $\begin{array}{l}\text { fasilitator, dinamisator, mediator dan } \\
\text { motivator. }\end{array}$ & \begin{tabular}{l} 
Pembimbing, fasilitator. \\
\hline $\begin{array}{l}\text { Posisi peserta } \\
\text { didik }\end{array}$
\end{tabular} Sebagai pusat kegiatan pembelajaran \\
\hline
\end{tabular}

Berdasarkan tabel 1, dapat dijelaskan dan ditarik relevansinya dalam pembahasan berikut ini:

Pendidikan humanisme Paulo Freire merupakan pendidikan yang memanusiakan manusia, dan menempatkan manusia pada posisi sentral dalam setiap perubahan yang terjadi dan mampu pula mengarahkan serta mengendalikan perubahan itu. Perubahan yang terjadi melalui proses pembelajaran merupakan suatu bentuk proses belajar menemukan kembali (reinventing), menciptakan kembali (recreating), menulis ulang (rewriting) (Freire, 2009:67). Ketiga bentuk ini hanya bisa dilakukan oleh subjek. Pendidikan kita selama ini hanya berfungsi untuk membunuh krativitas siswa, karena lebih mengedepankan aspek verbalisme, yaitu suatu asas pendidikan yang mengedepankan hafalan, bukan pemahaman, dan mengedepankan formulasi bukan substansi, serta lebih dalam lagi menyukai keseragaman, bukan kemandirian serta huru-hara klasikal, bukan petualangan intelektual (Yunus, 2004: ix).

Keberhasilan dalam pendidikan yang ditekankan pada kemampuan intelektual, kemampuan dalam menciptakan dan menerapkan suatu produk teknologi (yang merupakan terapan dari IPA), dan tanpa memperhatikan karakter sosial maupun spiritual, menjadi tugas para praktisi pendidikan untuk menyelesaikannya. Paulo Freire menyarankan adanya pendidikan dialektis, yang mampu mentransformasi karakter dan sikap sosial, yaitu menghargai 
pendapat dan pilihan orang lain, nilai kejujuran, keadilan, kemanusiaan, kesetiakawanan, pofesionalisme, keluhuran, kedisiplinan, dan ketulusan. Dialog mengandalkan adanya kerendahan hati. Seseorang mau belajar dari orang lain, meskipun dari segi budaya dianggap lebih rendah, memperlakukan orang lain dengan cara yang sama. Manusia pada hakikatnya adalah menjadi subjek yang harus mengubah dunia, membuat kehidupan ini semakin penuh dan semakin kaya, baik secara individual maupun secara kolektif. Dialog menuntut sikap mau mendengar dan memahami diri sendiri, menekankan adanya interaksi yang dialogis antara keduanya dalam menciptakan pengetahuan bersama. Guru sebagai subjek yang mengetahui ilmu, akan sangat tepat jika siswa juga memperoleh pemahaman yang sama tentang ilmu itu. Posisi kedua pihak adalah setara dan sederajat dalam proses pembelajaran.

Freire berusaha membongkar watak pasif dari praktik pendidikan tradisional, karena pendidikan dengan pola ini menempatkan siswa sebagai objek pembelajaran, dan melanggengkan "sistem relasi penindasan”. Disebutnya juga sebagai sistem pendidikan "gaya bank" yaitu guru bertindak sebagai pihak yang menabung pengetahuan, dan siswa penerimanya.

Pendidikan IPA di sekolah dasar dilakukan dengan memberikan pengalaman belajar secara langsung, melalui metode discovery maupun inquiry. Bukan memberikan sesuatu yang abstrak yang seolah-olah terpisah dari kehidupan nyata dari siswa. Sesuai dengan pendidikan yang membebaskan dari Paulo freire, guru mengkondisikan siswa agar mampu mengenal dan mengungkap kehidupannya secara kritis. Paulo Freire menekankan pada kebebasan intelektual antara pendidik dengan peserta didik, melalui dialog terbuka. Penemuan produk-produk IPA melalui inquiry maupun discovery memberikan kebebasan intelektual bagi siswa untuk lebih berfikir kritis. Selama proses penemuan, siswa akan saling berdiskusi dalam dialog terbuka. Pendidik dan siswa berada pada posisi sejajar dan saling belajar dan saling bekerja sama. Freire memperjelas konsep ini dengan memberikan ciri-ciri guru yang membebaskan: a) terbuka terhadap kritikan dari pihak eksternal selama itu baik bagi pembangunan yang lebih dinamis dan konstruktif menuju pendidikan yang membebaskan, b) merasa tidak cukup dengan ilmu yang didapatnya, sehingga memiliki keinginan belajar terus menerus tanpa henti, c) tidak merasa menjadi yang paling mampu dan menguasai berbagai hal, dan menganggap murid juga sumber informasi yang bisa ia ambil pelajaran dari mereka.

Mansyur (2014: 50), menyatakan tentang pendidikan kritis dari Paulo Freire, bahwa pendidikan selalu melibatkan hubungan sosial dan pilihan-pilihan politik. Ketika pendidikan memiliki hubungan yang erat dengan sosial, maka pendidikan akan memberikan pengaruh terhadap perubahan sosial yang ada. Hal ini sejalan dengan teori belajar Bandura, bahwa perilaku manusia selalu berkesinambungan antara kognitif, perilaku dan pengaruh lingkungan.

Dinyatakan oleh Muakhirin (2014), bahwa dalam kurikulum IPA sekolah dasar, pembelajaran IPA sebaiknya memuat 3 komponen, yaitu: pembelajaran IPA harus merangsang pertumbuhan intelektual dan perkembangan siswa, dengan melibatkan siswa dalam kegiatan praktikum/ percobaan 
IPA, dan seharusnya mendorong terbentuknya sikap ilmiah, mengembangkan kemampuan penggunaan keterampilan berfikir kritis dan rasional, melalui pembelajaran inquiry, yang dilakukan secara berkelompok. Dengan demikian, ada interaksi timbal balik antarsiswa, dan antara guru dengan siswa melalui sebuah proses dialog untuk menciptakan pemahaman dan pengetahuan bersama, yang mana hal ini sesuai dengan pemikiran Paulo Freire. Hanya dengan menempatkan siswa sebagai subjek, bukan objek dalam pembelajaran bisa mendorong siswa untuk berfikir secara kritis dan rasional.

Pembelajaran inquiry berpusat pada pertanyaan 'mengapa' dan 'bagaimana kita mengetahui', sehingga anak dituntut untuk berfikir kritis, dan didorong untuk menjelaskan tentang apa yang diamati dalam diskusi kelas maupun tulisan. Pembelajaran IPA sebagai proses aktif dan sangat dipengaruhi oleh keingintahuan siswa terhadap apa yang akan dipelajari. Paulo Freire menempatkan siswa sebagai pusat kegiatan pembelajaran, demikian juga dalam pendidikan IPA di sekolah dasar, yang menempatkan siswa sebagai subjek pembelajaran yang aktif. Peran pendidik sebagai pembimbing, fasilitator, dinamisator, mediator dan motivator.

Hasil belajar tidak hanya tergantung pada objek yang disiapkan oleh guru, tetapi juga oleh interaksi antara berbagai informasi yang seharusnya diberikan kepada anak serta mengkaitkannya dengan pengetahuan yang sebelumnya sudah dimiliki. Konteks pendidikan IPA yang humanistis, yaitu bagaimana mengajarkan IPA dengan cara memanusiakan manusia, sebagai seorang pendidik perlu memperhatikan aspek penting, yaitu a) memahami bahwa siswa memiliki bekal pengetahuan yang berhubungan dengan sesuat yang dipelajari, b) memahami aktivitas anak dalam melakukan kegiatan yang nyata, c) mendorong terciptanya kondisi untuk saling bertanya antara guru dan siswa.

\section{SIMPULAN}

Simpulan dari penelitian ini adalah:

1. Pendidikan IPA di sekolah dasar diarahkan melalui pengalaman langsung, dilakukan secara discovery dan inquiry ilmiah dengan mengembangkan keterampilan proses dan sikap ilmiah.

2. Model pendidikan menurut Paulo Freire menyatakan tentang pendidikan:

a) dialektis, yaitu interaksi yang dialog is antara guru dan siswa.

b) Pendidikan yang membebaskan dan tidak membelenggu, yaitu mengenal dan mengungkap realitas kehidupan secara kritis.

c) pendidikan humanisme, yaitu pendidikan yang memanusiakan manusia.

3. Tujuan pendidikan Paulo Freire adalah menghasilkan perubahan pada diri siswa baik perubahan dalam kualitas berfikir, kualitas pribadi, kualitas sosial, kualitas kemandiriannya dan kualitas kemasyarakatannya

4. Relevansi Pendidikan IPA sekolah dasar di Indonesia dengan pendidikan Paulo Freire:

a. Pendidikan humanis dari Paulo Freire, menempatkan manusia sesuai martabatnya. Dalam pembelajaran IPA, siswa sebagai subjek pembelajar yang diberi kebebasan intelektual untuk mengembangkan kemampuan berpikir kritis dan 
bersikap ilmiah melalui metode discovery dan inquiry, melalui dialog terbuka.

b. Tujuan pendidikan Paulo Freire mengarah pada perubahan kualitas cara berfikir, yang sejalan dengan tujuan pendidikan IPA di sekolah dasar yang mulai mengembangkan kemampuan untuk berfikir kritis sebagai bentuk dari perubahan berfikir pasif.

c. Pendidikan Paulo Freire menempatkan peserta didik sebagai subjek yang aktif dalam pembelajaran, sedangkan peran pendidik sebagai fasilitator, mediator, dan motivator. Demikian halnya dengan pendidikan IPA di sekolah dasar.
Hasil penelitian ini dapat direkomendasikan kepada para praktisi pendidikan untuk membelajarkan IPA di sekolah dasar dengan memberikan pengalaman secara langsung melalui proses inquiry ilmiah dengan melakukan pembelajaran secara dialogis, pembelajaran yang membebaskan sehingga dapat berfikir secara kritis dan rasional, dan pendidikan yang humanistis, yaitu pendidikan yang memanusiakan manusia.

\section{DAFTAR PUSTAKA}

Depdiknas. 2006. Peraturan Menteri Pendidikan Nasional Nomor 22 Tahun 2006 tentang Standar Isi untuk Satuan Pendidikan Dasar dan Menengah: Jakarta: Kemendiknas.

Djumhana, Nana \& Muslim. 2007. Pendidikan IPA. Jakarta: Direktorat Pendidikan Tinggi. Departemen Pendidikan Nasional.

Freire, Paulo. 2009. Politik Pendidikan. Kebudayaan Kekuasaan dan Pembebasan. Yogyakarta: Pustaka Pelajar.

Kemdikbud. 2013. Permendikbud Nomor 67 Tahun 2013 tentang Kerangka Dasar dan Struktur Kurikulum Sekolah dasar/ Madrasah Ibtidaiyah. Jakarta: Kemdikbud.

Mansyur, Masykur H. 2014. Pendidikan Ala "Paulo Freire" Sebuah Renungan Jurnal Ilmiah Solusi Vol. 1 No.1 Januari - Maret 2014: 64-76.

Muakhirin, Binti. 2014. "Peningkatan Hasil Belajar IPA Melalui Pendekatan Pembelajaran Inquiry Pada Siswa Sekolah Dasar". Jurnal Ilmiah Guru "COPE”, No. 01/Tahun XVIII/Mei 2014 
Shor, Ira \& Paulo Freire. 2001. Menjadi Guru Merdeka. Terj. A. Nashir Budiman Yogyakarta: LkiS.

Siswanto. 2007. "Pendidikan Sebagai Paradigma Pembebasan (Telaah Filsafat Pendidikan Paulo Freire)". Jurnal Tadris. Volume 2. Nomor 2.

Samatowa, Usman. 2011. Pembelajaran IPA di Sekolah dasar. Jakarta: PT Indeks

Yamin, Muh. 2010. "Menggugat Pendidikan Indonesia: Belajar dari Paulo Freire dan Ki Hajar Dewantara”. Jurnal Pendidikan. Volume 3. Nomor 2. 